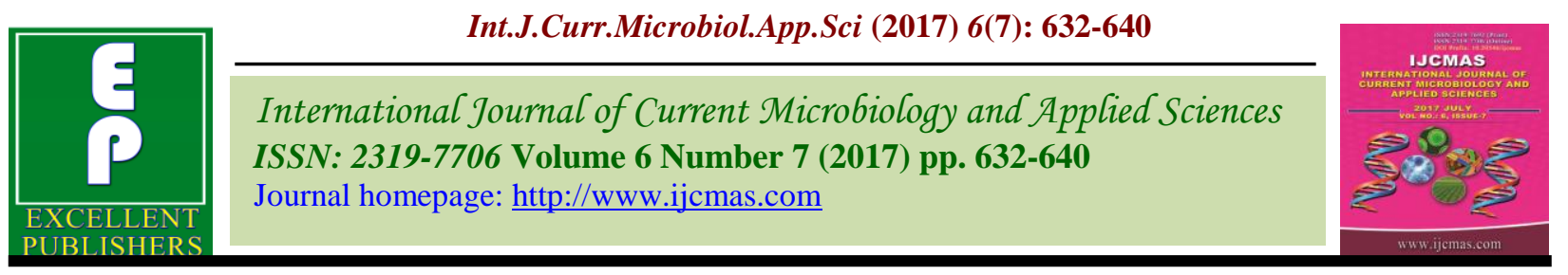

Original Research Article

https://doi.org/10.20546/ijcmas.2017.607.077

\title{
Isolation, Characterization and Pathogenesis of Ustilaginoidea virens Causing False Smut Disease in Rice (Oryza sativa L.)
}

\author{
D.G. Manu ${ }^{1 *}$, S.S. Pramoda ${ }^{2}$, A. Ramanathan², S. Ramchander ${ }^{1}$, \\ S. Manonmani ${ }^{1}$, P. Jeyaprakash ${ }^{1}$ and S. Robin ${ }^{1}$ \\ ${ }^{1}$ Department of Rice, Centre for Plant Breeding and Genetics, \\ ${ }^{2}$ Department of Plant Pathology, Centre for Plant Protection Studies, \\ Tamil Nadu Agricultural University, Coimbatore, Tamil Nadu, India -641003 \\ *Corresponding author
}

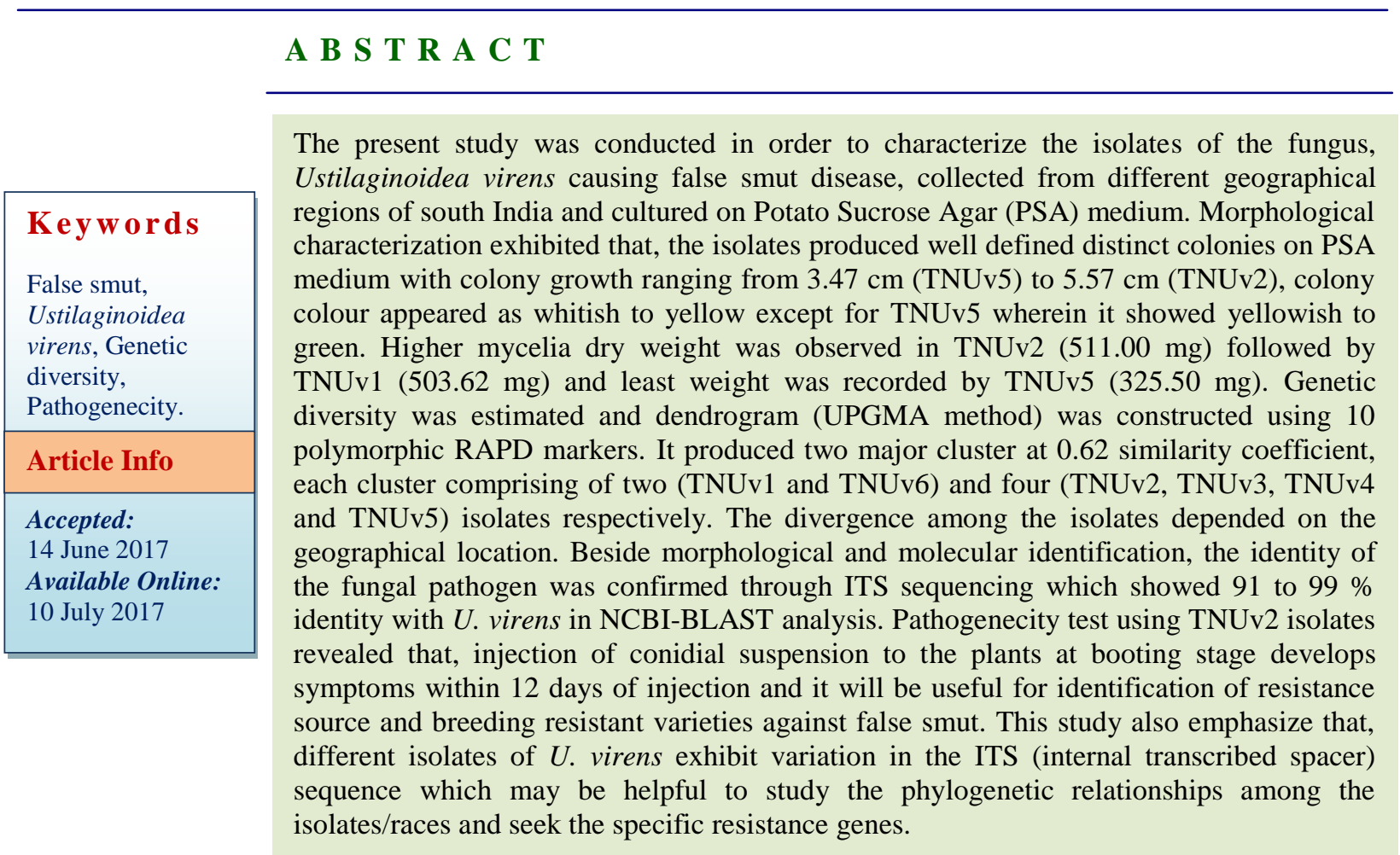

\section{Introduction}

False smut (Green smut or pseudo smut) is a common grain disease of rice around the world, caused by Ustilaginoidea virens (Cooke) (Takahashi). Recently Villosiclova virens has been proposed as the new name for teleomorph of the false smut fungus (White et al., 2000; Tanaka et al., 2008; Ashizawa et al., 2010). The fungus overwinters in soil by means of sclerotia and chlamydospores. Sclerotia produce ascospores, which are the primary source of infection to rice plants, whereas secondary infection comes from airborne chlamydospores (Ashizawa et al., 2010). Infection by the pathogen transforms 
individual grains of infected panicles into initially orange, becoming yellowish green or greenish black at maturity (Ou, 1972; Lee and Gunnell, 1992). The disease was first reported from Tirunelveli district of Tamil Nadu State of India (Cooke, 1878). Historically being an uncommon and minor disease by occurring sporadically in certain regions (Ou, 1972; Dodan et al., 1996), now epidemics of the disease is being reported frequently (Rush et al., 2000; Singh and Pophaly, 2010; Ladhalakshmi et al., 2012). This disease is considered as farmer's friendly and locally known as "Lakshmi" (meaning wealth) disease because it is found associated with bumper yields. However, the disease has been observed in severe form since 2001 due to widespread cultivation of high fertilizerresponsive cultivars and hybrids, heavy application of nitrogenous fertilizer and change in climate (Yaegashi et al., 1989; Sugha et al., 1993; Lu et al., 2009). In India the disease has been observed in major ricegrowing states viz., Haryana, Punjab, Uttar Pradesh, Uttaranchal, Tamil Nadu, Karnataka, Andhra Pradesh, Bihar, Jharkhand, Gujarat, Maharastra, Jammu and Kashmir and Puducherry (Dodan, 1996; Mandhare et al., 2008; Ladhalakshmi et al., 2012).

Since $U$. virens is very slow growing fungus, it is very difficult to isolate in its pure form. It often gets contaminated by the fast growing saprophytes during isolation, incubation and also difficult to be created artificially under screen house or field conditions. The development of suitable medium for growth and sporulation would facilitate further studies. Practical stand-point, a medium capable of stimulating sporulation of the fungus would aid in the preparation of spore suspension required for inoculation of large populations in disease resistance breeding programs. The disease not only threatens rice production in yield and quality but the chlamydospores also contaminate the rice grains and straw with their antimitotic cyclic peptides (ustiloxin) which are dangerous to the health of human and livestocks (Nakamura et al., 1992; Luduena et al., 1994; Ashizawa et al., 2011). In India the research on false smut has been negligible because of its minor importance and partly due to a problem in the artificial culturing and inoculation of the pathogen. With all these points in mind, the present study was carried out to study/assess the variability of the pathogen collected from various geographical locations and standardization of artificial inoculation technique for large scale screening of rice genotypes in order to identify resistant source against false smut.

\section{Materials and Methods}

\section{Sample collection}

The samples of typical false smut on rice (Fig. 1) were collected from different geographical regions viz., Hyderabad (IIRR), Paddy Breeding Station (Tamil Nadu Agricultural University, Coimbatore), Department of Agronomy (Wetland, TNAU Coimbatore), Hybrid Rice Evaluation Centre (HREC, Gudalur), farmers fields of Thanjavur, and Gobichettipalayam during 2016. Latitude, longitudes and annual mean temperature of site of collection were depicted on map (Fig. 2).

\section{Isolation, purification and maintenance of the pathogen}

The collected smut balls were surface sterilized by dipping them in $70 \%$ ethanol followed by $0.1 \%$ mercuric chloride and subsequently washed with sterile distilled water. Using a sterilized inoculation loop, the mass of chlamydospores were streaked onto Petri dishes containing potato sucrose agar medium (PSA) under aseptic condition. To avoid bacterial contamination, Streptomycin 
@ 100 ppm per litre was added in the medium at lukewarm stage before pouring into Petri plates. The Petri dishes were incubated at 27 $\pm 2{ }^{\circ} \mathrm{C}$ until the appearance of mycelium. A single, well isolated colony of the fungus was picked up using sterilized needle and transferred to the fresh PSA slants and maintained as a pure culture. Six isolates were purified and maintained on PSA medium at $4^{\circ} \mathrm{C}$. Thus, the purified cultures were maintained by periodical transfers on PSA slants, they were serially numbered (TNUv1 to TNUv6) and used for further studies (Table $1)$.

\section{Cultural and morphological characterization}

In order to study the detailed cultural characteristics of the pathogen, $5 \mathrm{~mm}$ mycelial discs were collected from ten days old culture of $U$. virens and inoculated at the center of PSA plates in three replicates under aseptic cultural condition $\left(27 \pm 2{ }^{\circ} \mathrm{C}\right.$ temp). After 30 days of inoculation (DAI) the observations were recorded on growth of the pathogen on the solid media viz., colony colour, colony diameter, growth type and mycelia dry weight. Radial mycelium growth was measured at 10 days interval $\left(10^{\text {th }}, 20^{\text {th }}\right.$, $30^{\text {th }}$ DAI). Mycelial dry weight of each isolate was observed by culturing the fungus on potato sucrose broth. Two mycelial discs of $5 \mathrm{~mm}$ of each isolates were inoculated in the broth and the flasks were incubated at 27 $\pm 2{ }^{\circ} \mathrm{C}$ temperature for 30 days. Culture filtrate along with mycelial mats were filtered on Whatman No. 1 filter paper and dried in the oven at $60{ }^{\circ} \mathrm{C}$ for 3 hours, the weight of the mycelial mats were recorded.

\section{Diversity analysis}

\section{DNA extraction}

All the six isolates were cultured in $50 \mathrm{ml}$ liquid potato sucrose broth in a $100 \mathrm{ml}$ conical flask at $26^{\circ} \mathrm{C}$ and shaken at $200 \mathrm{rpm}$. After 7 days, the culture was transferred to 50 $\mathrm{ml}$ liquid potato sucrose broth in a $250 \mathrm{ml}$ conical flask and incubated under the same conditions for 3 days. The mycelia were harvested and immediately ground into a fine powder by liquid nitrogen for DNA extraction following the protocol described by Nakada et al., (1994). Concentrations of DNA were estimated by measuring absorbance at $260 \mathrm{~nm}$ with a Nanodrop (GENOVA NANO, UK). DNA samples were diluted to working solutions of $30 \mathrm{ng} / \mu \mathrm{l}$ and stored at $4{ }^{\circ} \mathrm{C}$ until use.

\section{RAPD amplification and data analysis}

Fourteen random decamer RAPD primers (Table 2) were used to survey the isolates. Amplifications were performed in a total volume of $25 \mu \mathrm{l}$ containing $0.5 \mu \mathrm{d}$ dNTPs mix (10mM), $1 \mu \mathrm{l}$ primer $(12.5 \mathrm{pmol}), 2 \mathrm{ml}$ of DNA $(30 \mathrm{ng} / \mu \mathrm{l}), 1.2 \mu \mathrm{l} \mathrm{MgCl} 2,1.5 \mu \mathrm{l}$ reaction buffer $(10 \mathrm{X}), 0.3 \mu \mathrm{l}$ of $\mathrm{Taq}$ polymerase $(1.5 \mathrm{U})$ and $18.5 \mu \mathrm{l}$ deionized water. The DNA amplification was done in a thermal cycler (BioRad, USA) using the following PCR cycles. The first denaturation step of 2 minutes at $94{ }^{\circ} \mathrm{C}$, followed by 35 cycles of denaturation for $30 \mathrm{sec}$ at $94{ }^{\circ} \mathrm{C}$, annealing for $1 \mathrm{~min}$ at $40^{\circ} \mathrm{C}$, extension at $72^{\circ} \mathrm{C}$ for $2 \mathrm{~min}$ and final extension at $72{ }^{\circ} \mathrm{C}$ for 5 min with holding temperature at $4^{\circ} \mathrm{C}$ for 10 min. Reaction products $(8 \mu \mathrm{l})$ were resolved by electrophoresis in $1.2 \%$ agarose gels stained with ethidium bromide in $1 \mathrm{X}$ TBE buffer at $100 \mathrm{~V}$ for $90 \mathrm{~min}$. Differences in banding patterns among isolates were assessed visually using gel documentation system (BioRad, USA). Polymorphisms including faint bands that could be scored were included in the analyses. Polymorphic RAPD markers were manually scored as binary data with presence as (1) and absence as (0). The similarity matrix was then subjected to the unweighted pair group method with arithmetical mean (UPGMA) 
cluster analysis by using NTSYSpc version $2.02 \mathrm{i}$.

PCR amplification and sequencing of ITS region

Based on the RAPD diversity study, four diverse isolates were selected out of six and examined for the amplification of ITS region, which is having gene cluster of ITS1, 5.8S and ITS2. ITS region specific primers ITS1 F (5'-TCCGTAGGTGAACCTGCGG-3') and ITS4 R (5'-TCCTCCGCTTATTGATATGC3') designed by White et al., (1990) were used for PCR amplification. Reaction products $(8 \mu 1)$ were resolved by electrophoresis in $1.2 \%$ agarose gels stained with ethidium bromide in 1X TBE buffer at $100 \mathrm{~V}$ for 90 min. After electrophoresis the gel slice along with PCR fragments were excised with a clean, sharp scalpel. Then, they were purified using QIAquick Gel Purification Kit (QIAGEN, California) according to the manufacturer's protocol. The purified DNA from ITS-PCR was given for sequencing to Bioserve solutions, Hyderabad. The partial sequence of rDNA was obtained and it was submitted to the National Centre for Biotechnology Information (NCBI), Gene Bank, New York, USA and accession numbers were obtained (KX421100, KX421101, KX421102 and KX421103) (Table 3).

\section{Pathogenicity test}

Paddy variety BPT 5204 (Samba Mashuri) plants were brought to the screen house from main field at booting stage. The plants were inoculated with conidial suspension as described by Fujita et al., (1989). Pure culture of fast growing (TNUv2) isolate was inoculated into $100 \mathrm{ml}$ of potato sucrose broth (PSB) and kept in an incubator shaker (125 $\mathrm{rpm})$ at $28^{\circ} \mathrm{C}$ for 2 weeks for incubation. The conidia were harvested and suspended in sterile distilled water. Plants at booting stage were selected for inoculation and injected with $2 \mathrm{ml}$ of conidial suspension $\left(1 \times 10^{5}\right.$ conidia $\mathrm{ml}^{-1}$ ). The inoculated plants were kept in a humidity chamber with an $\mathrm{RH}$ of $95 \%$ and $24-26^{\circ} \mathrm{C}$ temperature in screen house. The rice panicles injected with sterile distilled water served as control.

\section{Results and Discussion}

\section{Morphological characterization of $\boldsymbol{U}$. virens}

The isolates produced well defined colonies on PSA medium. Maximum colony growth of $5.57 \mathrm{~cm}$ was observed in TNUv2 followed by TNUv3 $(5.07 \mathrm{~cm})$, whereas minimum colony growth of $3.47 \mathrm{~cm}$ in TNUv5. The colony colors in most of the isolates were initially white and turned to yellow. However, TNUv5 isolate alone showed greenish yellow even after incubation period of 30 days. Most of the isolates produced raised hat like structures except TNUv1and TNUv2, which showed flat growth in culture media. The highest mycelial dry weight was observed in TNUv2 (511.00 $\mathrm{mg}$ ) followed by TNUv1 (503.62 $\mathrm{mg})$ and the lowest was in TNUv5 (325.50 mg) (Table 4).

\section{Molecular characterization of $U$. virens using RAPD markers}

Genomic DNA was isolated from six different isolates and subjected to RAPDPCR amplification using 14 random decamer primers. Out of 14 primers, 10 RAPD (Table 2) primers produced reproducible and scorable polymorphic bands. The size of RAPD fragments on $1.2 \%$ agarose gel ranged from 100 to $2000 \mathrm{bp}$ (Fig. 3). The Jaccard similarity coefficient values among $U$. virens isolates ranged from 0.51 to 0.96 . The dendrogram constructed through UPGMA analysis clearly grouped the isolates into two major clusters at 0.62 similarity coefficient (Fig. 4). Dendrogram consist of two major 
clusters A and B. The isolates TNUv1 (Hyderabad) and TNUv6 (Gobichettipalayam) coming under cluster A and TNUv2 (PBS, Coimbatore), TNUv3 (Wetland, Coimbatore), TNUv4 (Gudalur) and TNUv5 (Thanjavur) belongs to cluster B. There were two sub clusters (BI and BII) were observed under major cluster $\mathrm{B}$, BI consist of three isolates TNUv2 (PBS, Coimbatore), TNUv3 (Wetland, Coimbatore), TNUv4 (Gudalur), where isolates TNUv3 and TNUv4 showed a relative genetic similarity value of 0.96. The isolate TNUv5 (Thanjavur) belongs to BII sub cluster. Although, major clustering supported the geographical origin of isolates in general, critical analysis revealed that fine clustering does not support exact geographical origin of isolates and their genetic properties. The information obtained from sequencing of isolates viz., TNUv1, TNUv2, TNUv4 and TNUv5 had 678 (95\%), 612 (99\%), $674(97 \%)$ and $649(91 \%)$ base pairs respectively. Inside the parenthesis says per cent coverage identity in BLAST search http://www.ncbi.nih.gov/index.html (Table $3)$.

The rice variety BPT 5204 was used to test the pathogenicity of the isolated fungus by artificially injecting the conidial suspension of TNUv2 to the tillers at the booting stage. Out of ten inoculated plants, three plants produced typical false smut balls on the panicles with 30 percentage of diseased hill $(\mathrm{PDH})$ after 12 days of inoculation. $U$. virens infected the young ovary of the individual spikelets and transformed them into large, velvety green balls. Young smut balls were fleshy inside and became hard after some time. Initially the smut balls were small, visible between glumes and were covered with a membrane that burst at a later stage (Fig. 5).

False smut disease is commonly occurring in the wet season all over the world. Flowering stage coinciding with rains and high humidity, many of the high yielding rice varieties succumb to varied level of infection. Limited information is available on the pathogen diversity and hence this study becomes relevant. The pathogen was characterized based on its colony and spore morphology, which produced pure white coloured, raised, smooth colony margin and on continuous incubation, the colour converted to light yellow and in some cases green. Similar morphological characteristics of the pathogen were described by Hegde et al., (2000) and Ladhalakshmi et al., (2012) in rice. The isolates produced well defined colonies on potato sucrose agar medium with colony growth ranging from 3.47 to $5.57 \mathrm{~cm}$ after 30 days of incubation. Initially the colony growth was creamy white colour resembling straw hat shape with undulations, which turned yellowish after 20-25 days of incubation. In the culture medium the chlamydospore burst and appears after 30- 40 days after incubation at $27{ }^{\circ} \mathrm{C}$. The colour of the mycelium changed white to yellow and later greenish yellow resembling symptoms in the field. These results agreed with Ladhalakshmi et al., (2012) and Baite et al., (2015). In culture medium $U$. virens proliferated and produced creamy-white colony, flat or rose with slight undulations, mycelium fluffy, compact and leathery. Chlamydospores were observed at the centre or margin of the colony at later stage of growth.

RAPD markers were used to estimate genetic variation in $U$. virens and to determine if any of population structure occurred with regard to geographical origin. The UPGMA algorithm constructed a neighbor joining tree which grouped the isolates into two major clusters at 0.62 Jaccard similarity coefficients (Fig. 4). Cluster A comprised of two isolates TNUv1 (Hyderabad) and TNUv6 (Gobichettipalayam). Cluster B comprised of four isolates which were again subdivided into two subgroups. The first subgroup (BI) 
comprise of three isolates, out of which two isolates TNUv3 (Wetlands, Coimbatore) and TNUv4 (Gudalur) with 0.96 similarity coefficient and TNUv2 (PBS, Coimbatore) different from other isolates of same subgroup, the only isolate TNUv5 (Thanjavur) belongs to second subgroup (BII). In earlier studies RAPD marker system has been used successfully to characterize molecular variation in $U$. virens ( $\mathrm{Li}$ et al., 2004; Xiao-ping et al., 2008; Mathew et al., 2014). Our results suggest that RAPD markers can be used to evaluate genetic diversity within the species $U$. virens through estimates of variation at multiple loci across the genome.
The advent of molecular biology has caused a significant shift in the types of approaches used to identify and characterize plant pathogens and to device management strategies. The polymerase chain reaction (PCR) method has been developed for the in vitro amplification of nucleic acid sequence and has been used to detect a number of plant pathogens based on the specific nucleotide sequences. This method is highly sensitive and capable of detecting even a single copy of DNA molecule (Henson and French, 1993). PCR based technique was used for detection and characterization of $U$. virens based on the Internal Transcribed Spacer (ITS) regions of ribosomal DNA (rDNA).

Table.1 Isolates collected from different locations

\begin{tabular}{|c|l|}
\hline Isolates & \multicolumn{1}{|c|}{ Place of collection } \\
\hline TNUv1 & Indian Institute of Rice Research, Hyderabad \\
\hline TNUv2 & Paddy Breeding Station, Coimbatore \\
\hline TNUv3 & Wetland Farm, Coimbatore \\
\hline TNUv4 & Hybrid Rice Evaluation Centre, Gudalur, The Nilgiris \\
\hline TNUv5 & Farmer field, Thanjavur \\
\hline TNUv6 & Farmer field, Gobichettipalayam \\
\hline
\end{tabular}

Table.2 Primers used for RAPD-PCR amplification of $U$. virens isolates

\begin{tabular}{|c|c|c|}
\hline Primer name & Primer sequence 5'-3' & Nature of primer \\
\hline OPK07 & AGCGAGCAAG & Polymorphic \\
\hline OPF03 & CCTGATCACC & Polymorphic \\
\hline OPG02 & GGCACTGAGG & Polymorphic \\
\hline OPD20 & ACCCGGTCAC & Polymorphic \\
\hline OPA-08 & GTGACGTAGG & Monomorphic \\
\hline OPB-09 & TGGGGGACTC & Monomorphic \\
\hline OPG17 & ACGACCGACA & Polymorphic \\
\hline OPE03 & CCAGATCGAC & Polymorphic \\
\hline OPL17 & AGCCTGAGCC & Polymorphic \\
\hline OPC10 & TGTCTGGGTG & Polymorphic \\
\hline OPG06 & GTGCCTAACC & Polymorphic \\
\hline OPC-11 & AAAGCTGCGC & Monomorphic \\
\hline OPE-14 & TGCGGCTGAG & Monomorphic \\
\hline OPM16 & GTAACCAGCC & Polymorphic \\
\hline
\end{tabular}


Table.3 Fungal identification based on NCBI-BLAST search (for ITS1-5.8s-ITS4 region)

\begin{tabular}{|c|l|c|c|c|c|}
\hline Isolates & \multicolumn{1}{|c|}{ Source } & $\begin{array}{c}\text { Accession } \\
\text { number }\end{array}$ & $\begin{array}{c}\text { Base pair } \\
\text { length }\end{array}$ & $\begin{array}{c}\text { Species } \\
\text { identified as }\end{array}$ & $\begin{array}{c}\text { Coverage } \\
\text { identity (\%) }\end{array}$ \\
\hline TNUv1 & Hyderabad & KX421100 & 678 & U. virens & 95 \\
\hline TNUv2 & Coimbatore & KX421101 & 612 & U. virens & 99 \\
\hline TNUv4 & Gudalur & KX421102 & 674 & U. virens & 97 \\
\hline TNUv5 & Thanjavur & KX421103 & 649 & U. virens & 91 \\
\hline
\end{tabular}

Table.4 Cultural and morphological characteristics of different isolates of $U$. virens on PSA medium

\begin{tabular}{|c|c|c|c|c|c|c|}
\hline \multirow[b]{2}{*}{ Isolates } & \multicolumn{3}{|c|}{$\begin{array}{l}\text { Radial mycelium growth } \\
(\mathbf{c m})\end{array}$} & \multirow{2}{*}{$\begin{array}{c}\text { Dry weight } \\
\text { (mg) } \\
\mathbf{3 0} \text { (DAI) }\end{array}$} & \multirow{2}{*}{$\begin{array}{l}\text { Colony } \\
\text { colour }\end{array}$} & \multirow[b]{2}{*}{ Growth type } \\
\hline & $\begin{array}{l}\mathbf{1 0}^{\text {th }} \\
\text { day }\end{array}$ & $20^{\text {th }}$ & $\begin{array}{l}\text { 30 }^{\text {th }} \\
\text { day }\end{array}$ & & & \\
\hline TNUv1 & $\begin{array}{c}1.3 \\
(1.14)^{\mathrm{c}}\end{array}$ & $\begin{array}{c}3.07 \\
(1.75)^{\mathrm{c}}\end{array}$ & $\begin{array}{c}5.00 \\
(2.24)^{\mathrm{b}}\end{array}$ & $\begin{array}{c}503.62 \\
(22.44)^{\mathrm{a}}\end{array}$ & $\begin{array}{l}\text { Creamy } \\
\text { white }\end{array}$ & $\begin{array}{c}\text { Flat, Fluffy and } \\
\text { Circular }\end{array}$ \\
\hline TNUv2 & $\begin{array}{c}1.88 \\
(1.37)^{\mathrm{a}}\end{array}$ & $\begin{array}{c}3.93 \\
(1.98)^{\mathrm{a}}\end{array}$ & $\begin{array}{c}5.57 \\
(2.36) \mathrm{a}\end{array}$ & $\begin{array}{l}511.00 \\
(22.61)^{\mathrm{a}}\end{array}$ & $\begin{array}{l}\text { White to } \\
\text { yellow }\end{array}$ & Flat and Circular \\
\hline TNUv3 & $\begin{array}{c}1.61 \\
(1.27)^{b}\end{array}$ & $\begin{array}{c}3.46 \\
(1.86)^{b}\end{array}$ & $\begin{array}{c}5.07 \\
(2.25)^{b}\end{array}$ & $\begin{array}{c}421.75 \\
(20.54)^{b}\end{array}$ & $\begin{array}{c}\text { Yellowish } \\
\text { white }\end{array}$ & $\begin{array}{l}\text { Raised, Fluffy and } \\
\text { Circular }\end{array}$ \\
\hline TNUv4 & $\begin{array}{c}1.17 \\
(1.08)^{\mathrm{c}}\end{array}$ & $\begin{array}{c}2.8 \\
(1.67)^{\mathrm{d}}\end{array}$ & $\begin{array}{c}4.5 \\
(2.12)^{c}\end{array}$ & $\begin{array}{l}479.75 \\
(21.90)^{\mathrm{a}}\end{array}$ & $\begin{array}{l}\text { White to } \\
\text { yellow }\end{array}$ & $\begin{array}{l}\text { Flat, Fluffy and } \\
\text { irregular }\end{array}$ \\
\hline TNUv5 & $\begin{array}{c}0.88 \\
(0.94)^{\mathrm{d}} \\
\end{array}$ & $\begin{array}{r}2.35 \\
(1.53)^{\mathrm{e}}\end{array}$ & $\begin{array}{c}3.47 \\
(1.86)^{\mathrm{e}} \\
\end{array}$ & $\begin{array}{c}325.50 \\
(18.04)^{\mathrm{c}}\end{array}$ & $\begin{array}{c}\begin{array}{c}\text { Yellow to } \\
\text { green }\end{array} \\
\end{array}$ & Raised, irregular \\
\hline TNUv6 & $\begin{array}{c}1.00 \\
(1.00)^{\mathrm{d}}\end{array}$ & $\begin{array}{c}2.3 \\
(1.52)^{\mathrm{e}}\end{array}$ & $\begin{array}{c}3.92 \\
(1.98)^{\mathrm{d}}\end{array}$ & $\begin{array}{c}339.25 \\
(18.42)^{\mathrm{c}}\end{array}$ & $\begin{array}{l}\text { White to } \\
\text { yellow }\end{array}$ & $\begin{array}{l}\text { Raised, fluffy } \\
\text { irregular }\end{array}$ \\
\hline SE (d) & 0.03 & 0.03 & 0.03 & 0.42 & - & - \\
\hline $\mathrm{CD}(\mathrm{P}=\mathbf{0 . 0 5})$ & 0.07 & 0.07 & 0.06 & 0.90 & - & - \\
\hline
\end{tabular}

Figures in parentheses represent square root transformation. Means in a column followed by same superscript letters are not significantly different according to DMRT

Results revealed that all the four isolates amplified a fragment of $625 \mathrm{bp}$ for universal ITS primer (ITS1/ ITS 4). The results agreed with Baite et al., (2015) who observed sequence length of Uv2 (Bulandshahr, Uttar Pradesh) and Uv3 (Haridwar, Uttarakhand) with 645 and 634 respectively and the identity was $98-99 \%$. It is thus indicated that identity of the fungus could be confirmed by sequencing PCR products of ITS regions using primers. It is necessary to develop an efficient inoculation method for investigation of the rice- $U$. virens interaction. Up to date, quite a few reports consistently conclude that inoculation by injection of spores into the sheath during booting stage is sufficient and efficient to induce disease symptoms. Wang et al., (2008) obtained a white smut strain that is virulent to rice plants, with this strain, it was found that disease severity is higher by injection than by spraying. Low temperature exposure after inoculation has a strong stimulatory effect on disease development (Kulkarni and Moniz, 1975; Fujita et al., 1989; 
Hegde et al., 1998; and Xiu et al., 2011; Ladhalaxmi et al., 2012). Lu et al., (2009) studied the pathogenic diversity of $U$. virens by injecting the conidial inoculum of the fungus during the booting stage under field conditions. Ashizawa et al., (2010) developed a modified method of artificial inoculation by injecting the conidial inoculum of the fungus. Haiyong et al., (2015), injected a conidial suspension $\left(1 \times 10^{6}\right.$ conidia $\mathrm{ml}^{-1}$ ) of $U$. virens at the booting stage and incubated the plants in a moist cabinet initially at $15^{\circ} \mathrm{C}$ for 2 days, and then at $26^{\circ} \mathrm{C}$ for 5 days. Similar results were observed by injection of the conidial inoculum produced by artificially culturing the fungus, led to typical false smut symptoms under glasshouse conditions.

Genetic improvement of rice for false smut resistance is in need of a robust and moderate throughput screening methods for identification of genes and genotypes conferring resistance to false smut. The study has brought out some leads on the pathogenesity and isolates diversity that would carry forward the research in the right context.

\section{Acknowledgement}

The authors are grateful to Indian Council of Agricultural Research (ICAR), New Delhi for providing financial assistance through the Crop Research Platform, "Incentivizing Agriculture".

\section{Conflict of Interest}

Authors certify that there is no financial commitment to the sponsor. Authors also state that they have full control of all primary data and that they agree to allow the journal to review their data if requested.

\section{References}

Ashizawa, T., Takahashi, M., Moriwaki, J., Hirayae, K. 2010. Quantification of the rice false smut pathogen Ustilaginoidea virens from soil in Japan using real-time PCR. Eur. J. Plant Pathol., 128(2): 221-232.
Ashizawa, T., Takahashi, M., Moriwaki, J., Hirayae, K. 2011. A refined inoculation method to evaluate false smut resistance in rice. J. Genet. Pl. Pathol., 77(1): 10-16.

Baite, M.S., Sharma, R.K. 2015. Isolation technique and culture conditions of false smut pathogen. Ustilaginoidea virens. of rice. Indian Phytopathol., 68(1): 50-55.

Cooke, M.C. 1878. Some extra European fungi. Grevillea, 7: 13-15.

Dodan, D.S., Ram, S., Sunder, S. 1996. False smut of rice: Present status. Agril. Rev., 17: 227-240.

Fujita, Y., Sonoda, R., Yaegashi, H. 1989. Inoculation with conidiospores of false smut fungus to rice panicles at booting stage. Ann. Phytopathol. Soc. Japan, 55: 629-634.

Haiyong, H., Wongkaew, S., Jie, Y., Xuehui, Y., Xiaojun, C., Shiping, W., Qigqun, T., Lishuang, W., Sompong, M., Buensanteai, N. 2015. Biology and artificial inoculation of Ustilaginoidea virens. Cooke). Takahashi in rice. Afr. J. Microbiol. Res., 9(11): 821-830.

Hegde, Y.R. 1998. Biology and Management of False Smut of Rice. Oryza sativa L. caused by Claviceps oryzae sativa Hashioka in Karnataka. Karnataka J. Agric. Sci., 13(3): 623-627.

Hegde, Y.R., Anahosur, K.H., Kulkarni, S. 2000. Morphological and cultural studies on Claviceps Oryzae sativae a causal agent of false smut of rice. Karnataka J. Agric. Sci., 13(4): 1005-1008.

Henson, M.J., French, R. 1993. The polymerase chain reaction and plant disease diagnosis. Annu Rev. Phytopathol., 31: 81-109.

Kulkarni, C.S., Moniz, L. 1975. False smut of Rice -An airborne disease. Curr. Sci., 44: 483-484.

Ladhalakshmi, D., Laha, G.S., Ram, S., Karthikeyan, A., Mangrauthia, S.K., Sundaram, R.M., Thukkaiyannan, P., Viraktamath, B.C. 2012. Isolation and characterization of Ustilaginoidea virens and survey of false smut disease of rice in India. Phytoparasitica, 40: 171-176.

Lee, F.N., Gunnell, P.S. 1992. False smut Compendium of rice diseases St Paul: American Phytopathol. Soc., 28. 
Li, Z.Y., Juan, F.J., Zhen, Z.C., Zhou, L.X., Shu, W., Jun, K.K. 2004. Preliminary analysis of genetic diversity and population structure of Ustilaginoidea virens. Acta Phytopathol., 34(5): 442-448.

Lu, D.H., Yang, X.Q., Mao, J.H., Ye, H.L., Wang, P., Chen, Y.P., He, Z.Q., Chen, F. 2009. Characterizing the pathogenicity diversity of $U$ virens in hybrid rice in China. J. Plant Pathol., 91: 443-451.

Ludueńa, R.F., Roach, M.C., Prasad, V., Banerjee, M., Koiso, Y. 1994. Interaction of ustiloxin with bovine brain tubulin. Biochem. Pharmacol., 47:1593-1599.

Mandhare, V.K., Gawade, S.B., Game, B.C., Padule, D.N. 2008. Prevalence and incidence of bunt and false smut in paddy. Oryza sativa L. seeds, Maharashtra Agric. Sci. Digest, 28(4): 292-294.

Mathew, S.B., Sharma, R.K., Prameela, D.T., Pratibha, S., Deeba. 2014. Morphological and molecular characterization of $U$ virens isolates causing false smut of rice in India. Indian Phytopathol, 67(3): 222-227.

Nakada, M., Tanaka, C., Tsunewaki, K., Tsuda, M. 1994. RFLP analysis for species separation in genera Bipolaris and Curvularia. Mycosci., 35: 271-278.

Nakamura, K., Izumiyama, N., Ohtsubo, K., Koiso, Y., Iwasaki, S., Sonoda, R., Fujita, Y., Yaegashi, H., Sato, Z. 1992. Lupinosis in mice caused by ustiloxin and a crude extract of fungal culture of $U$ virens. Proc. Jpn. Assoc. Mycotoxicol., 35: 41-43.

Ou, S.H. 1972. Rice diseases Commonwealth Mycological Institute Kew.

Rush, M.C., Shahjahan, A.K.M., Jones, J.P. 2000. Outbreak of false smut of rice in Louisiana. Pl Dis., 84(1): 100.
Singh, A.K., Pophaly, D.J. 2010. An unusual rice false smut epidemic reported in Raigarh District Chhattisgarh. Int. Rice Res. Notes, 35: 1-3.

Sugha, S.K., Sharma, O.P., Kaushik, R.P. 1993. Performance of rice genotypes against false smut pathogen under rainfed conditions. $\mathrm{Pl}$. Dis. Res., 8: 76-77.

Tanaka, E., Tanaka, C. 2008. Phylogenetic study of Clavicipitaceous fungi using acetaldehyde dehydrogenase gene sequences. Mycosci., 49:115-125.

Wang, S., Li, M., Dong, H., Liu, X.Z., Bai, Y.J. 2008. Sporulation inoculation methods and pathogenicity of Ustilaginoidea albicans the cause of white rice false smut in China. J. Phytopathol., 156: 755-757.

White, J.F., Sullivan, R., Moy, M., Patel, R., Duncan, R. 2000. An overview of problems in the classification of plant parasitic Clavicipitaceae. Studies in Mycol., 45: 95105.

White, T.J., Bruns, T.D., Lee, S.B., Taylor, J.W. 1990. Amplification and direct sequencing of fungal ribosomal RNA genes for phylogenetics. PCR Protocols: a Guide to Methods and Applications, 315-322.

Xiao-ping, T., Jian-wei, S., Er-ming, L., Nian-xi, L., Jin-hui, W., Qi-ming, X. 2008. Analysis of genetic diversity of $U$. virens in Hunan. Natural Sci., 34(6): 694-697.

Xiu, Y., Shu, W., Lin, L., Xin, Y.D., Raun, C. 2011. Study on characteristics of the mycelial growth and conidia germination of U virens. J. Fujian Agric. Forestry Univ., 40(6): 576-581.

Yaegashi, H., Fujita, Y., Sonoda, R. 1989. Severe outbreak of false smut of rice in 1988. Plant Prot. Tokyo, 43: 311-314.

\section{How to cite this article:}

Manu, D.G., S.S. Pramoda, A. Ramanathan, S. Ramchander, S. Manonmani, P. Jeyaprakash and Robin, S. 2017. Isolation, Characterization and Pathogenesis of Ustilaginoidea virens Causing False Smut Disease in Rice (Oryza sativa L.). Int.J.Curr.Microbiol.App.Sci. 6(7): 632-640. doi: https://doi.org/10.20546/ijcmas.2017.607.077 